\title{
Subversive Ambiguity in the Poetry of Delmira Agustini, Alfonsina Storni, and Giovanna Pollarolo
}

\author{
Sara Villa \\ The New School, New York, USA
}

\begin{abstract}
This paper analyzes the poetry of Delmira Agustini, Alfonsina Storni, and Giovanna Pollarolo, three Latin American poets who collectively spanned the arc of the 20th century, in order to demonstrate that they were all acting to subvert certain stereotypical notions propagated by society and by canonical literature. While Agustini used a parodic discourse to deconstruct the sacrality of masculinity, Storni employed parody and excessive, calculated use of quotes from canonical male authors to subvert the traditional images and roles assigned to women. Parody, hyperbolic images, and ambiguity will be analyzed here as the major literary means used by these two poets to criticize the deep-rooted, gendered discourse of their times. Pollarolo's poetry, as well as that of Storni, will be analyzed as "minor” literature, as described in the theories of Deleuze and Guattari.
\end{abstract}

Keywords: subversive poetry, parody, hypebole, canonic discourse, deconstructive images, Latin America

\section{Introduction}

It might appear an arduous endeavour to try to analyze in a single essay three poets whose work was written during the span of a century and which expressed, consequently, very different concerns and needs. In the case of these poets-Agustini, Storni, and Pollarolo—it is not as complicated as it may seem, since all of them used the same linguistic devices to defend themselves against the role assigned to them.

The purpose of this work is to come to an understanding of how these three poets used a variety of methods to fight against the sanctioned, anti-feminist stereotypes and attitudes so deeply rooted in the literary canon. This paper will demonstrate how, through hyperbolic and grotesque images, each was able to defeat not only the stereotypes that have become canonical in the masculine world but also the ones that have been circulating among women. It will also be evident that, behind the apparent reverence to the canon in their poetry, there hides in fact a strong desire to subvert the canonic discourse.

\section{Delmira Agustini: Deconstructing Sacrality}

Delmira Agustini and Alfonsina Storni are two poets who worked within, respectively, a modernist period and a postmodern period. None of the two was able to escape from the refined, the artificial, and the exotic

Sara Villa, Ph.D., assistant professor of Spanish, Department of Foreign Language, School of Language and Learning, The New School. 
aspects that Modernism had left as an inheritance. The poems “Capricho” by Agustini (1924) and "Lo blanco" by Storni (1916) are clear examples of that.

Nevertheless, the modernist vein vanishes soon in their poetry to leave space to, especially in Agustini's case, a more personalized poetry. It is clear, however, that the modernist echoes do not disappear completely nor suddenly in their writing. In the book El libro blanco (1907) by Agustini, we notice a rejection of the euphony so typical of the modernist movement. This rejection is very well expressed in the poem "Rebelión" (1913), a clear example of her subversiveness in the treatment of rhyme. There are also a series of poems where the use of hyperbolic images allows the author to subvert the traditional stereotypes about women. "El intruso", a poem that belongs to the collection Los astros del abismo (1924), describes a night of romantic love during which the lover-intruder is presented almost as a celestial being who, with a golden key, opens the door where he finds the narrative voice. His form/shape, a "mancha de luz y blancura”, converts him into a semi-ethereal creature, an idea reinforced in the following lines where the poet describes the "intruder" in a more idealized way. His eyes become diamonds that glow, and his head is fragrant. The lines that follow portray a woman who totally erases herself, annihilates her being under his light. She is the dog that sleeps at his feet, the one who blends into her shadow the fresh smell of her man, the one who laughs when he laughs and sings only when he sings. So it is clear in these lines that there is a perfect representation of the woman-shadow of the male partner, the faithful dog who never separates from her man. This clichéd image, as we will see, is taken to its extreme through parody, used here with the purpose of subverting entirely the final message.

At the end of the poem, Agustini reiterates through more hyporbole the reverential, almost religious "slavery" to which she succumbs. The trembling feeling that she has when he touches the doorknob gives the reader the sensation/feeling that we are facing a superhuman. Nevertheless, at the same time, we sense the ridicule of these images aimed at deconstructing the deity and sacrality of man.

Other poems also confirm the use of a repertoire of extremely hyperbolic images to represent the relation man-woman. One of these poems belongs to the book El Rosario de Eros (1924), a poem that even in the title betrayes a doubtful religious reference.

Altough not all the poems in this book can be analyzed by the same way, the poem "Oh tú" (Agustini, 1924, p. 55) is significant for the use of certain images that provoke the opposite effect of what they seem to propose.

Reflecting the life of the poet, the poem is divided into two parts. The first describes the melancholic state in which she has lived her life till the arrival of her man. Agustini (1924) uses images such as the owl of "de las ruinas ilustres y las almas altas y desoladas" (p. 56), the night, the tower, the spiders—all typical of the gothic repertoire - to describe this melancholic state. All of a sudden we witness a change that is equivalent to the one that has happened in the second part of her life. The reiterated pronoun "tú" in the following lines reveals with no doubts the person responsible for her miracoulous rescue:

¡Oh, tú que me arrancaste a la torre más fuerte!

Que alzaste suavemente la sombra como un velo,

Que me lograste rosas en la nieve del alma,

Que me lograste llamas en el mármol del cuerpo

Que hiciste todo un lago con cisnes, de mi lloro.... (Agustini, 1924, p. 56) 
The poet is thus calling the omnipotent man who is being transformed into a semi-God. For this particular invocation — which has a clear parodic tone-Agustini has chosen images that, not by chance, refer to objects that belong to religious ritual: The shiny chalice, the woman as the wife or daughter of God carrying a lily and the man himself addressed as Lord.

One more time then, Augustini is trying to deconstruct a myth — that of a man who is a semi-God—with the help of exaggerated images that border on blasphemy.

\section{Alfonsina Storni: Parodic Discourse}

The second poet analyzed in this essay is Alfonsina Storni. Like Agustini, Storni passed through a variety of poetic phases. After an initial period marked by a less defined style with modernist influences, her production abondons the stereotype of the pure, holy, and abandoned woman figure. The poems that follow are progressively more imbued with a parody and an irony aimed at exposing the demystifying operations that are now taking place in her poetry.

With "Hombre pequeñito”, “La armadura”, "Bien pudiera ser”, and "La ronda de las muchachas”, it is clear that the author's goal is to subvert the traditional images and roles assigned to women. "La armadura" is very close to being a revolutionary manifesto. The author's voice is firmer, with fewer ambiguities, and acquires a collective voice that is typical of "minority" literature whose fight concerns group identity. So, as her poems become more like pamphlets, the protest takes a more direct approach.

The poem "Oye" in Irremediablemente (1919) reinforces from the beginning the same image of an obliterated woman that we have seen in Delmira Agustini. Storni (1919) plays with the cliché of a submissive woman who, next to her man, becomes nothing, turning into:

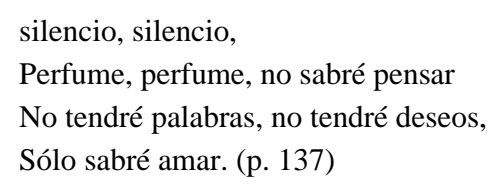

The exaggeration of the cliché, taken to the limits of the absurd, is accompanied by another feature typical of women's writing:

The homage-quote of the text, style and genre of the prestigious canonized words, is used to obtain the benevolence of the audience and to validate her own poetic voice. [...]. (Reisz, 1994a, p. 71)

la cita-homenaje del texto, el estilo o el género evocados, en la que la autora utiliza el prestigio de la palabra canonizada para ganar la benevolencia del público y validar su propia voz [...]. (Reisz, 1994a, p. 71)

In this case perhaps the poet Neruda is being indirectly quoted with lines from "Me gustas cuando callas" from the book Veinte poemas de amor y una canción desesperada (1924). In this way the author is accomplishing two things: She is validating herself through the quote of a canonical author, and at the same time, she is subverting the image through the exaggerated quote. All the while she is establishing an ironic distance from what is being imitated.

In "El hombre sereno" (1919), we notice again a similarity with Agustini’s poem. We encounter the same ironic description of the man as a generous, prudent, serene, and beautiful human being. The parody reaches its climax in the final lines when the woman erases herself completely in front of his omnipotence and omniscience: 
Con sus palabras hablo; su ventura es la mía;

Me infundo en sus deseos, me pierdo en su energía,

Porque todo lo puede, porque todo lo sabe. (Storni, 1968, p. 139)

“Tú me quieres blanca” (1918) is a poem entirely constructed through the reiteretion of the cliché of the woman as white, chaste and pure. The poet is once again borrowing the images from another canonical author, Sor Juan Inés de la Cruz, and is taking the image to its extreme in order to deconstruct it and surpass it. The whole emotional power, accumulated in the first verses in which the author seems to reiterate the representation that women have of men, reaches its climax in the following stanza:

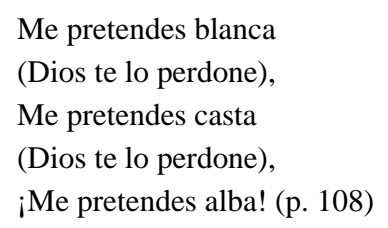

What comes after this stanza are a series of challenges that she proposes to the man and that allow to show his hypocrisy.

A final poem analyzed here is "Saludo al hombre" (1925). Seemingly, we experience the same tone and the same attitude toward the masculine figure. The only difference is that now the man is, instead of an omnipotent God, a kind of Roman Emperor. The title itself suggests an oratorical tone, and this poetic key is indeed realized in the poem itself. Compared to him, the feminine voice can only lay down the coat of arms and admit her defeat. Next to him, born to win and triumph, she is only able to toast humbly to him and end her poem with these classic lines: “¡Salud! En versos te hago mi fina reverencia” (Storni, 1925, p. 270).

\section{Pollarolo’s “Minor” Poetry}

Until now our analysis of the poetry of Agustini and Storni has focused on the parodic imitation of themes and language typical of canonical literature. This strategy allowed them to defend themselves from the stereotypes of the antifeminism group. This seems to be the same path followed by Giovanna Pollarolo. Entre mujeres solas (1995) shows in the title itself—which is a direct quote from a Pavese short story - the need to be among those Latin American authors who, knowing or not that they lack a language of their own, use the citation of canonical authors to take ownership of the language. With this overtly open gesture, Pollarolo is trying to win the reader's sympathy and, at the same time, to establish an ironic distance with what she is imitating (Reisz, 1994a, p. 134).

Once we start reading the text, the presence of a choir of poetic voices stands out:

El yo poético confesional se refracta desde un comienzo en una multiplicidad de voces ficcionales distribuidas, a la manera de una novela, entre una narradora primaria o principal y una serie de personaje femeninos monologantes o dialogantes a los que áquella se dirige o a los que implícitamente les cede la palabra. (Reisz, 1994a, p. 130)

With respect to this, if we think that the Bakhtinian theory exposed in "El discurso en la novella" (from Estética de la creación verbal) excludes from all poetic text a polyphony of voices, because it regards them as typical of a narrative text and not a poetic one, we understand how Pollarolo is consciously fighting against a long established tradition. It is exactly for this reason that her texts can be read as example of "minor" literature, 
especially if we take into account the definition offered by Deleuze and Guattari in which they reelaborated Kafka's theories.

The word "minor" in reference to women does not imply a quantitative judgement nor does it refer to power. The term simply underlines the marginal role that women have always played and continue to play in patriarchal societies where there is few or no public space reserved to them.

According to Deleuze and Guattari (1986), we can talk about a "minor literature" when we are looking at a literature constructed by a minority but moving within the realm of a mainstream language.

If we borrow the example of Jewish literature of German speakers, Deleuze and Guattari (1986) apply the term "minor" to all those literatures that, within the mainstream literature, are able to define a voice that can embrace several marginal ethnic groups. For this kind of literature Deleuze and Guattari identify several essential subversive features that can also be applied to Pollarolo's texts.

The first essential element would be the decentralization of language, meaning a language uprooted from its primordial territory and "turned strange in the location where is being placed" (Deleuze \& Guattari, 1986, p. 133). A perfect example of this would be the German used by Kafka, who, instead of using the most elevated German, tried "to take the language to the desert" (Deleuze \& Guattari, 1986, p. 26). The second key element for a minor literature would be that everything in it "must be political”. In this kind of literature the social environment has a background function (Deleuze \& Guattari, 1986, p. 17). The third and last feature would be a "collectiveness" seen in this kind of literature. Since it comes out of a community with little or reduced power, the very few literary voices end up portaying themselves as representantives of a community.

As for the collective aspect of Pollarolo's text, it is clearly present in Entre mujeres solas, in which the conversations among women echo women's issues of different social classes. In "Reencuentros", there are women who have been betrayed by life and who now are surprised to discover that they are longing for their old dreams: “Como no podíamos saber que veinte años después/estamos soñando al revés” (Pollarolo, 1995, p. 14). We are aware from the very beginning that the poetic voice is a group of women talking in first person plural in the present and in the past. The poem is filled with: "tenemos”, “decimos", "vernos", "hablábamos”, "teníamos”, "hacemos”, “leemos”, “reímos”, “somos”, “recordamos”, “comemos”, and "bebemos”. On other occasions we see the woman who, trapped in her monotonous routine, hates her Saturdays and detest her Sundays; another who is considered lucky by the others who do not know how bored she is; another who is the one who can only function in relation to him who, on the other hand, does not listen to her, and does not look at her; yet another who refuses sex vehemently; and finally all those others who have seen their honeymoon vanish quickly. All of them have reacted differently to their circumstances:

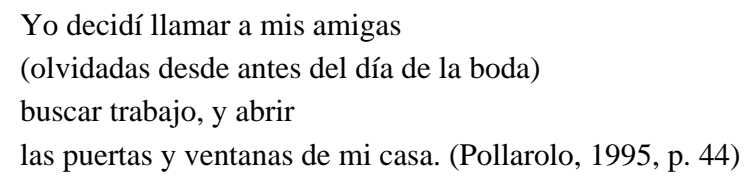

Another one says:

A mí pasó igual; pero yo no llamé a nadie

no hice nada

sólo lloré. (Pollarolo, 1995, p. 44) 
Nevertheless, for each one of these women, there is a reader capable of indentifying with her and with her circumstances. The considerable success of this book is proof of that, notwithstanding the limitations posed by a title that seems to address just an audience of women.

Behind the ensemble of poetic voices there is a clear intention of creating a bifurcation or a "plurifurcation" of the masculine and feminine values and preoccupations. In the poem "Confesión” there is an ensemble of voices. First we hear the husband who confesses his infidelity, then we hear the narrative voice criticizing the husband and ultimately becoming a collective voice with the final declaration "¡Por los hombres, qué mal pagan!” (Pollarolo, 1995, p. 25).

Another example of this device of several "fictional" voices is found in the poem "Otra noche" (Pollarolo, 1995, p. 39). Here the voice of the narrator and that of a friend are interposed. He dreams about his youth and about his never-confessed love for her while revealing to her his desire to fulfill his dream by making love to her. But she is tired now and the contrast between his erotic dream and her real dream of wanting to go to sleep becomes stronger. In the end, their voices get mixed with the narrator's and with that of the protagonist, who is dialoguing with God:

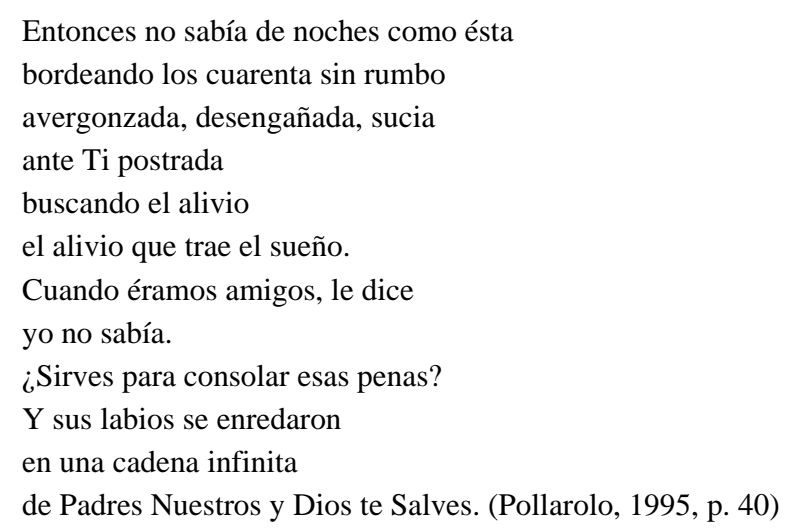

The political value of this text becomes clear in the condemnation of the feminine role as a negative or subordinate one, unable to develop and ultimately "minor", inferior. There is a clear accusation of all those stereotypes of the woman as mother-wife-sister whose chores are cleaning, ironing, washing clothes, preparing food, taking care of children, consoling their men and making love with them. Although not aware anymore of who exactly she is, she has not forgotten her role (Pollarolo, 1995, p. 60). These are all women who have become "white paper” (Pollarolo, 1995, p. 64), whose destiny has been foreseen:

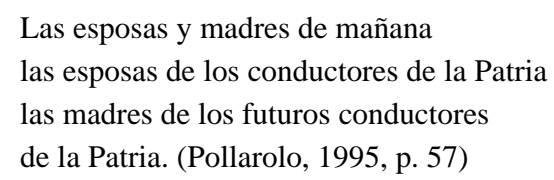

They are the wives or the mothers of the winners, but they are not triumphant. That is why the poem ends with the sarcastic “¡He ahí el privilegio!” referring to the privilege of having been elected (maybe by God) to accomplish such a difficult mission. 
The religious references that we find in the poem are insincere. The women compare their men to God. They have both created a role for the woman, a role that, in the end, is the same. That is how life has always been for these women and that is how it will always be. Even when they think that they have changed their life with a lover, they are unware of the fact that, ultimately, nothing has changed, and that: “... él y él se parecen/casi como dos gotas de agua" (Pollarolo, 1995, p. 49).

It is as if, among all these women, the only one who can walk placidly and with no fear is the one who sees men like equals and has put an end to love and sex. It is only in this way that it is possible for her to talk to herself in the mornings, sleep by herself but not see herslf as a mere projection of masculine desires.

The criticism toward the other gender is direct and often is based on the complaints of having to do household chores. At other times it responds to the physical pain suffered by his beating.

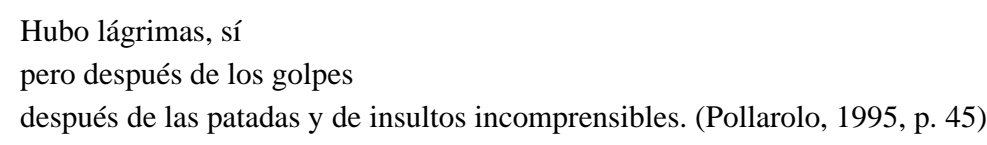

We also witness a repugnant feeling toward sex and copulation. This is clearly expressed in "Yo me hago la dormida" (Pollarolo, 1995, p. 32), where the repressed violence creeps under the sheets and make her feel, right after the sexual act, “el filo de un cuchillo” (Pollarolo, 1995, p. 32). As Reisz (1991) says: “... la politización de los tópicos literarios debe entenderse aquí-no en forma exclusiva pero sí prioritaria—como respuesta a cierta 'política sexual' dominante en nuestra sociedad” (p. 133).

After reading the first section of Entre mujeres solas, what surprises at first is the colloquial aspect of the poems. From the implicit declaration underlining the title, we already have the sensation of estrangements. It is a feeling that is produced by the transfer of narrative elements to poetry. The entire collection of poems is structured and organized like short stories. Pollarolo’s language is "vuelto extraño por exceso o por carencia en relación con el ámbito en que se inserta” (Reisz, 1991, p. 133). Her poetry is similar to a series of short debates that reflect well the image of a private reunion among old classmates talking about their current lives, their dreams and their faded hopes.

"Luna de miel” (1995), a good example of what was mentioned above, presents at least nine feminine voices. All of them talk about the change that occurred in their lives right after their honeymoon. There is the one who, after being forgotten by the husband, finds consolation in her friends; the one who is abandoned in favor of a boxing match. There is also the one who, after being repeatedly beaten, feels the growing hate in her husband. And through this gallery of women and their dysfunctions, we get to the narrator who, through her routine and vain hopes, converts herself into an animal, a "perra en celo" (Pollarolo, 1995, p. 47).

\section{Conclusions}

These three poets, Agustini, Storni, and Pollarolo, whose work covers an entire century, have made possible that their own voices and those of the women about whom they write, could be heard even in mainstream literature. In their work, an apparent reverence toward the literary canon conceals a subversive desire that each expresses through parody, hyperbolic and grotesque images, and finally through a kind of discourse that is considered "minor". 


\section{References}

Agustini, D. (1924). Obras completas de Delmira Agustini (The complete works of Delmira Agustini). Sarandí: El Siglo Ilustrado. Bakhtin, M. (1978). Estética de la creación verbal (Esthetics of creative discourse). México: Siglo XXI.

Deleuze, G., \& Guattari, F. (1986). Kafka: Toward a minor literature. (D. Polan, Trans.). Minneapolis, MN: University of Minnesota Press.

Pollarolo, G. (1995). Entre mujeres solas (Among women alone). Lima: Editorial El Santo Oficio.

Pollarolo, G. (1997). Las Cerimonias del Adiós (The farewell ceremonies). Lima: Peisá.

Reisz, S. (1991). Las mujeres sí tienen afán (Women do have ambition). Hueso, 28, 131-147.

Reisz, S. (1994a). Colectivismo versus universalismo: Voces e imágenes de mujer en la literatura de este fin de siglo (Collectivism vs universalism: Female voices and images in literature at the closing of this century). Actas del II Encuentro Internacional sobre Teorías y Prácticas Críticas. Mendoza.

Reisz, S. (1994b). Conflictos de "género” (y de géneros) en la poesía peruana de nuestro fin de siglo (“Genre” (and gender) conflicts in Peruvian poetry at the closing of this century) (En Actas del XXX Congreso del IILI, Pittsburgh).

Reisz, S. (1996). Voces sexuadas. Género y poesía en hispanoamérica (Sexualized voices: Genre and poetry in Latin America). Lleida: Edicions de la Universitat de Lleida.

Storni, A. (1968). Poesías completas (The complete poetry). Buenos Aires: Sociedad Editora Latino Americana. 